\title{
Bank Lending to Russian Enterprises in the Face of External Challenges
}

\author{
Piontkevich N.S. \\ Department of Finance, Money Circulation and Credit \\ Ural State University of Economics \\ Yekaterinburg, Russia \\ nspiont@gmail.com
}

\author{
Shatkovskaya E.G. \\ Department of Accounting and Audit \\ Ural State Mining University \\ Yekaterinburg, Russia \\ egshatkovskaya@gmail.com
}

\begin{abstract}
In this study, the analysis in the period of international sanctions, the situation on the corporate lending market of the Russian Federation is developed; the dynamics of credit investments of non-financial organizations sector of the economy are studied; trends in the sectoral structure of the corporate loan portfolio of the banking sector are revealed; the dynamics of credit portfolio quality of the banking sector in the categories of borrowers quality and the total aggregate corporate loan portfolio are assessed; the change in the share of overdue debt in loans to organizations in the context of economic activities is indicated.
\end{abstract}

The study processed extensive official statistical material on the Russian market of corporate Bank lending, identified prospects for improving the quality of the total corporate loan portfolio on the basis of the credit process digitalization, the development of more convenient and secure credit products and services.

Keywords-bank lending; loan portfolio; debt capital; overdue debt; loan quality; corporate Finance; digitalization

\section{INTRODUCTION}

Bank corporate lending performs the global function of capital redistribution in the national economy between territories and industries. By means of such redistribution there is a satisfaction of requirements in debt financing of one enterprises and reception of the additional income by economic subjects at which the released money on Deposit Bank accounts settle. In this context, Bank lending to enterprises is of strategic importance for the development of the national economy, especially given the current macroeconomic and political challenges in the world.

Corporate Bank lending is one of the main banking operations and at the same time acts as one of the most important ways of generating income of a credit institution. Efficiency of the enterprises Bank crediting depends both on the banks realizing in practice the credit policy formed by them, and on the enterprises receiving Bank debt financing. The latter, in turn, should assess the cost availability of the chosen source of financing [13, p. 43; 10, p. 275], since:
- the maturity of a Bank loan must match the completion date of the borrower assets turnover and the cash to the account;

- the total cost of a Bank loan should contribute to the effective use of these funds by the borrower in turnover and increase the profitability of its activities.

Due to its transparency, banking is vulnerable to external challenges and must respond promptly and adequately to all changes in the external and internal environment. First of all, this concerns the main direction of banking business-corporate lending to the economy.

\section{LITERATURE REVIEW}

Such scientists and practitioners as Aisyah Abdul-Rahman, Erbao Cao, Junhu Ruan, Lingxia Du, Mariani Abdul-Majid, Michaël Dewallya, Norfaizah Othman, Peter Benczur, Stelios Karagiannis, Virmantas Kvedaras, Yingying Shao addressed the problems of Bank lending to the corporate sector of the economy in the world scientific community [5, pp. 1-2; 7, pp. $223 ; 8$, p.1; 13, p. 1]

The problems of effective corporate Bank lending are investigated in the works of Russian scientists G. G. Korobova; O. I. Lavrushin, I. D. Mamonova, G. N. Beloglazova and others.

Russian economists V. S. Sergenyuk, E. S. Bobrikovich, Yu. I. Lopukh consider corporate lending in the activity of banks as the activity that brings the greatest income, and for legal entities as one of the ways to obtain financial support [12, p. 21].

According to the authors of this study, the main objectives of corporate Bank lending in the current environment of external challenges are:

- first, maintaining the volume of lending required by the market and increasing it, taking into account the needs of the national economy and the capabilities of the banking system;

- secondly, improving the quality of the corporate loan portfolio of the Russian Federation banking sector by reducing overdue loans to enterprises; 
- thirdly, the unification of corporate Bank lending processes, which allows to standardize the credit process and ensure the reduction of Bank costs for its maintenance;

- fourth, the digital transformation of banks credit activities, aimed at organizing the most personalized interaction with customers-borrowers.

The implementation of the tasks in practice is possible on the basis of the macroeconomic situation analysis in the Russian Federation and the initial situation in the corporate Bank lending market in the Russian Federation.

\section{RESEARCH METHODOLOGY}

As a methodological basis of the research, the article uses a set of basic methods, namely: scientific abstraction, logical, dialectical, statistical, comparative analysis method, expert evaluation method, economic-mathematical and dynamic methods.

The information base of the study was the information and analytical materials of the Russian Federation Central Bank on the development of the financial market, banking sector and banking supervision in 2016-2018.

Methodological base of research is the current procedure of classification of Bank loans contained in Bank of Russia Regulation N 590-P "On procedure of formation by credit organizations of reserves for possible losses on loans, loan and similar debt", dated 28 June 2017 [1].

\section{RESULTS}

The level of the national economy development determines the degree of its efficiency and competitiveness, as well as the position in the world economic system.

According to estimates of the Russian economy regulator in recent years, there are the following positive results:

- GDP growth was $1.5 \%$ (in 2017 there was a decrease of $0.2 \%)$;

- the foreign economic situation was favorable [6, p. 2];

- global production growth accelerated in 2018;

- prices for the main goods of Russian exports on the world markets have increased;

- investors ' interest in investments in assets of emerging markets increased, the inflow of portfolio investments in these countries increased;

- at the same time, the factor constraining the inflow of capital to Russia remained the extension of foreign countries sanctions [2, p. 24].

The activities of Bank credit institutions acting as financial intermediaries are affected by the emerging trends in the development of the national economy, burdened by international sanctions. At the same time, the stability of banks managing the cash flows of the state, economic entities and individuals directly affects the provision of financial stability at the macro and micro levels. These circumstances determine the importance of the national banking sector development analytical studies.

In general, in 2018, the assets of the banking sector increased by $9.0 \%$ to 85.2 trillion. The total volume of loans to legal entities of the non-financial sector and individuals increased by $6.2 \%$ to 42.4 trillion. In the corporate lending segment, there was also a noticeable positive trend, including interest rates on loans to non-financial organizations (table I).

TABLE I. BASIC INDICATORS OF LENDING TO THE CORPORATE SECTOR OF THE RUSSIAN FEDERATION IN 2016-2018

\begin{tabular}{|l|c|c|c|}
\hline \multicolumn{1}{|c|}{ Name of the indicator } & $\mathbf{2 0 1 6}$ & $\mathbf{2 0 1 7}$ & $\mathbf{2 0 1 8}$ \\
\hline $\begin{array}{l}\text { Growth rates since the beginning of the loans } \\
\text { year to non-financial organizations in 2017, } \\
\%\end{array}$ & - & $-1,8$ & 3,7 \\
\hline $\begin{array}{l}\text { Weighted average interest rates on ruble } \\
\text { loans to non-financial organizations for less } \\
\text { than 1 year, \% per annum }\end{array}$ & 13,4 & 11,6 & 9,4 \\
\hline $\begin{array}{l}\text { Weighted average interest rates on ruble } \\
\text { loans to non-financial organizations for more } \\
\text { than 1 year, \% per annum }\end{array}$ & 13,7 & 12,5 & 9,4 \\
\hline \begin{tabular}{l} 
Source: compiled by the authors: [11, c. 23, 25]. \\
\hline
\end{tabular}
\end{tabular}

Source: compiled by the authors: [11, c. 23, 25].

The dynamics of lending to organizations of different economic activity types in 2018 was multidirectional:

- lending to manufacturing enterprises in the Russian banking system remains the most significant and accounts for $22.3 \%$ of the corporate loan portfolio;

- increased loans to organizations engaged in mining $(24.4 \%)$ and operations with real estate, rent and services $(27.3 \%)$;

- loans to agricultural and forestry organizations increased by $9.2 \%$ (table II).

TABLE II. SECTORAL STRUCTURE OF THE CORPORATE LOAN PORTFOLIO OF THE RUSSIAN BANKING SECTOR IN 2016-2018, \%

\begin{tabular}{|l|c|c|c|}
\hline \multicolumn{1}{|c|}{ Economic activity } & $\mathbf{2 0 1 6}$ & $\mathbf{2 0 1 7}$ & $\mathbf{2 0 1 8}$ \\
\hline Extraction of minerals & 6,9 & 7,9 & 9,1 \\
\hline Manufacturing activity & 23,8 & 21,9 & 22,3 \\
\hline $\begin{array}{l}\text { Production and distribution of electricity, } \\
\text { gas and water }\end{array}$ & 3,5 & 4,4 & 4,6 \\
\hline Agriculture, hunting and forestry & 4,9 & 5,7 & 6,0 \\
\hline Construction & 6,7 & 6,4 & 5,6 \\
\hline Transport and communications & 5,8 & 6,0 & 6,2 \\
\hline Wholesale and retail trade & 15,6 & 15,5 & 13,9 \\
\hline $\begin{array}{l}\text { Real estate transactions, rental and provision } \\
\text { of services }\end{array}$ & 16,1 & 14,4 & 17,1 \\
\hline Other activities & 16,7 & 17,7 & 15,2 \\
\hline \multicolumn{2}{|l}{ Source: compiled by the authors: [11, c. 24]. }
\end{tabular}

An important positive achievement of 2018 in the conduct of banking operations is the activation of the devaluing assets process, which is due to both a decrease in the volume of loans in foreign currency terms and the strengthening of the ruble. Thus, the assets of credit institutions in foreign currency (in dollar equivalent) for 2018 decreased by $9.0 \%$, and their share in total assets - up to $22.3 \%$.

The share of foreign currency loans in the total loan portfolio to non-financial organizations decreased to $29.7 \%$ for loans to organizations of all economic activities, except for organizations engaged in the production and distribution of electricity, gas and water (table III). 
The deterioration in the quality of the corporate loan

TABLE III. SHARE OF DEBT IN FOREIGN CURRENCY IN LOANS TO ORGANIZATIONS BY TYPE OF ECONOMIC ACTIVITY IN THE RUSSIAN FEDERATION IN 2016-2018,\%

\begin{tabular}{|c|c|c|c|}
\hline Economic activity & 2016 & 2017 & 2018 \\
\hline Extraction of minerals & 58,5 & 46,4 & 39,9 \\
\hline Manufacturing activity & 34,9 & 30,1 & 27,9 \\
\hline $\begin{array}{l}\text { Production and distribution of } \\
\text { electricity, gas and water }\end{array}$ & 0,7 & 0,4 & 3,0 \\
\hline Agriculture, hunting and forestry & 2,2 & 1,3 & 1,3 \\
\hline Construction & 20,9 & 16,0 & 9,9 \\
\hline Transport and communications & 27,1 & 18,7 & 16,1 \\
\hline Wholesale and retail trade & 15,2 & 11,7 & 9,9 \\
\hline $\begin{array}{l}\text { Real estate transactions, rental and } \\
\text { provision of services }\end{array}$ & 38,2 & 31,8 & 28,8 \\
\hline Other activities & 30,5 & 22,1 & 20,5 \\
\hline
\end{tabular}

In terms of economic activities, the share of overdue debt decreased in all major sectors, except construction (growth from 15.8 to $17.9 \%$ ) and trade (growth from 11.8 to $12.2 \%$ ) (table IV).

TABLE IV. THE SHARE OF OVERDUE DEBT IN LOANS TO ORGANIZATIONS IN THE CONTEXT OF ECONOMIC ACTIVITIES IN THE RUSSIAN FEDERATION IN 2016-2018, \%

\begin{tabular}{|l|c|c|c|}
\hline \multicolumn{1}{|c|}{ Economic activity } & $\mathbf{2 0 1 6}$ & $\mathbf{2 0 1 7}$ & $\mathbf{2 0 1 8}$ \\
\hline Extraction of minerals & 3,7 & 1,2 & 0,5 \\
\hline Manufacturing activity & 4,0 & 4,1 & 4,0 \\
\hline $\begin{array}{l}\text { Production and distribution of } \\
\text { electricity, gas and water }\end{array}$ & 2,3 & 1,9 & 1,3 \\
\hline Agriculture, hunting and forestry & 9,5 & 8,6 & 7,7 \\
\hline Construction & 14,9 & 15,8 & 17,9 \\
\hline Transport and communications & 6,4 & 6,4 & 4,3 \\
\hline Wholesale and retail trade & 10,1 & 11,8 & 12,2 \\
\hline $\begin{array}{l}\text { Real estate transactions, rental and } \\
\text { provision of services }\end{array}$ & 5,2 & 6,2 & 5,5 \\
\hline Other activities & 4,8 & 4,5 & 5,2 \\
\hline \multicolumn{1}{|l}{ Source: compiled by the authors: [11, c. 47]. }
\end{tabular}

\section{DISCUSSION}

The quality of the Russian banks loan portfolio during the study period has not undergone significant changes. In 2018, the share of overdue debt in the total volume of corporate loans decreased by $10 \%$. This decrease is positive and is due to:

- faster growth of the loan portfolio compared to the growth of overdue debt-10.7 vs. $1.6 \%$;

- write-off and sales of problem loans-at the expense of reserves for possible losses due to the inability to recover, the loan debt was written off up to 0.5 trillion rubles [11].

As for the structure of the banking sector, the leaders in dealing with problem loans were banks with foreign participation-debt reduction occurred by $12.9 \%$, state-owned banks showed the opposite result-debt growth by $9.2 \%$. Nevertheless, state-owned banks still have the lowest share of overdue debt compared to other groups under consideration $3.2 \%$.

At the end of 2018, the share of I and II quality categories loans in the total volume of loans increased slightly and amounted to $83.2 \%$., the share of problem loans in the total corporate loan portfolio of Russian banks also increased by $0.2 \%$. portfolio is mainly due to the performance of sanitized banks, whose share of" bad " loans increased from 52.2 to $60.8 \%$. At the same time, the share of "bad" loans in loans to legal respectively, for state-owned banks and banks with a basic license.

Credit institutions, carrying out almost all types of financial activities, play a significant socio-economic role in the state [4, p. 443] and occupy a special place in the system of financial monitoring [3, p. 80]. in this regard, business lending as one of the main banking operations should be given considerable attention in order to ensure the profitability of the banking business and the corporate sector of the economy.

The authors see the improvement of the corporate loans quality in the active introduction of technological innovations in the organization of the credit process through:

- fundamental changes in the principles of service provision and business processes of interaction between banks and business;

- use of new digital tools and platform solutions to increase the volume and speed of transactions, on-line monitoring of the quality of loans.

\section{CONCLUSION}

An important aspect of the positive changes in the implementation of credit policy is to improve the quality of the loan portfolio - the share of overdue debt in the total volume of loans to the economy decreased by $0.1 \%$. This is due to the outstripping growth in the size of the loan portfolio compared to the growth of overdue debt -6.2 against $2.5 \%$.

The share of "good" loans-I and II categories of quality-in the total loan portfolio remained virtually unchanged and amounted to $82.5 \%$, but the share of loans of IV and V categories of quality increased to $10.0 \%$.

As for the corporate sector of the economy, the situation has almost stabilized:

- the share of overdue debt was $6.4 \%$;

- the growth rate of the corporate loan portfolio almost corresponds to the growth rate of overdue debt $(3.7 \%$ vs. 3.9 $\%$, respectively) (table $\mathrm{V}$ ).

TABLE V. ASSESSMENT OF THE RUSSIAN BANKING SECTOR CORPORATE LOAN PORTFOLIO QUALITY IN 2016-2018,\%

\begin{tabular}{|l|c|c|c|}
\hline \multicolumn{1}{|c|}{ Name of the indicator } & $\mathbf{2 0 1 6}$ & $\mathbf{2 0 1 7}$ & $\mathbf{2 0 1 8}$ \\
\hline $\begin{array}{l}\text { The volume of overdue debt in the } \\
\text { corporate loan portfolio of banks, billion } \\
\text { rubles. }\end{array}$ & - & 1892 & 1942 \\
\hline $\begin{array}{l}\text { The share of overdue debt on issued } \\
\text { loans to corporate customers, \% }\end{array}$ & 6,2 & 6,3 & 6,4 \\
\hline $\begin{array}{l}\text { Share of loans of IV and V categories of } \\
\text { quality ("bad" loans) in the total volume } \\
\text { of loans to legal entities (except CO) }\end{array}$ & 9,1 & 10,7 & 12,0 \\
\hline $\begin{array}{l}\text { Provisions for possible losses on loans to } \\
\text { legal entities (except CO) of IV and V } \\
\text { quality categories, } \% \text { of the total volume } \\
\text { of these loans }\end{array}$ & 64,1 & 62,4 & 65,9 \\
\hline
\end{tabular}
entities decreased from 6.7 to $5.9 \%$ and from 20.1 to $19.8 \%$, 
[7] Michaël Dewallya, Yingying Shao, Liquidity crisis, relationship lending and corporate finance, Journal of Banking \& Finance. 2014, 39, pp. 223239. URL: http://dx.doi.org/10.1016/j.jbankfin.2013.11.002

credit policy in the national banking system in the medium term may be offset by a high level of uncertainty in the further development of the world economy.

\section{References}

[1] About the order of formation by credit organizations of reserves for possible losses on loans, the loan and the debt equated to it: position of the Central Bank of the Russian Federation of June 28, 2017 N 590-P. "Consultant Plus": Legislation: version Prof - URL: http://www.consultant.ru/document/cons_doc_LAW_220089.

[2] Annual report of the Bank of Russia for 2018. URL: www.cbr.ru.

[3] Beketnova Yu. M. Analytical methods of assessment and forecasting of the financial condition of credit institutions. Finance: theory and practice. 2019, 23(1), 79-95. DOI: 10.26794/2587-5671-2019-23-1-7995

[4] Tendencies of development of activity of the Russian credit organizations in a section of analytical groups of Bank of Russia. Modernization of the Russian society: new economic reference points, management strategies, questions of law enforcement and training of personnel: collection of materials XX vseros. (NAT.). science. Conf. Taganrog. 2019, pp. 442-447.

[5] Erbao Cao, Lingxia Du, Junhu Ruan, Financing Preferences and Performance for an Emission-Dependent Supply Chain: Supplier vs. Bank, International Journal of Production Economics. 2018. doi: 10.1016/j.ijpe.2018.08.001

[6] Inromation-analytical materials «Financial stability review». 2018. URL: www.cbr.ru.

[8] Norfaizah Othman, Mariani Abdul-Majid, Aisyah Abdul-Rahman, Partnership financing and bank efficiency, Pacific-Basin Finance

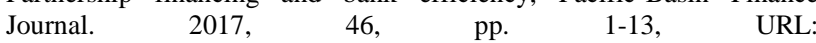
http://dx.doi.org/10.1016/j.pacfin.2017.08.002

[9] Peter Benczur, Stelios Karagiannis, Virmantas Kvedaras, Finance and economic growth: financing structure and non-linear impact, Journal of Macroeconomics. 2018. https://doi.org/10.1016/j.jmacro.2018.08.001

[10] Piontkevich, N. S. Availability of sources of financing for organizations in the conditions of cyclical development of the economy. Economics, law and education in the conditions of risk and uncertainty: trends and prospects of development: proceedings of the Conference. science.pract. Conf. (Nizhny Tagil, February 25, 2016). Yekaterinburg: Ural publishing House. state Econ. UN-TA. 2016, pp. 269-275.

[11] Report on the development of the banking sector and banking supervision in 2018. URL: www.cbr.ru.

[12] Sergenyuk V. S., Bobrikovich E. S., Lopukh Yu. I. the Main directions of improving the Bank's work on lending to corporate clients. Fundamentals of Economics, management and law. 2014, 2(14), pp. 21 24.

[13] Alexsandr S. Kuznetsov. Russian Professor's meeting. Russian Journal of Physical Education and Sport. 2019, 14(1), pp. 17-22. DOI: 10.14526/2070-4798-2019-14-1-18-24

[14] Shatkovskaya N. S. Formation of the monetary capital of the organization in the conditions of cyclic development of economy / N. S. Shatkovskaya: dis. ... Cand. Econ. sciences'. Ekaterinburg, 2012, 183. 